\title{
PENINGKATAN PENGETAHUAN TERKAIT PERKEMBANGAN DAN PEMERIKSAAN COVID-19 MELALUI WEBINAR PADA SISWA JURUSAN ANALIS KESEHATAN DI SMK BHAKTI KENCANA GARUT
}

\author{
Dwi Davidson Rihibiha, Fini Ainun Qolbi dan Iis Herawati \\ Prodi Teknologi Laboratorium Medis, STIKes Jenderal Achmad Yani Cimahi \\ E-mail: dwirihibiha@gmail.com
}

\begin{abstract}
ABSTRAK. Pada saat ini dunia sedang dilanda pandemi yang cukup mengkhawatirkan, yaitu Coronavirus Disease 2019 (Covid-19). Pemerintah Indonesia telah menetapkan status darurat bencana yang terkait dengan pandemi virus ini. Pemutusan rantai penularan dilakukan dengan menerapkan protokol kesehatan secara disiplin. Akan tetapi, masih banyak masyarakat yang tidak mengikuti anjuran tersebut. Sehubungan dengan hal tersebut, maka dilakukannya kegiatan Praktek Pembangunan Kesehatan Masyarakat (PPKM) yang merupakan suatu bentuk pendidikan dengan cara memberikan pengalaman belajar kepada mahasiswa untuk dapat mengidentifikasi serta menangani masalah-masalah kesehatan yang dihadapi di masyarakat. Kegiatan PPKM kali ini berupa sosialisasi secara daring dalam bentuk webinar dengan judul "Putuskan Rantai Penyebaran Covid! Pengentahuan, Pencegahan dan Pemberantasan (3P)" dengan peserta adalah siswa/i jurusan Analis Kesehatan, SMK Bhakti Kencana, Bayongbong, Garut. Webinar yang dilakukan terdiri dari paparan materi terkait perkembangan Covid-19 dan juga teknik pemeriksaan laboratorium Covid-19 sebagai wawasan tambahan pada siswa/i jurusan Analis Kesehatan. Hasil kuisioner menunjukkan peserta dari SMK Bhakti Kencana Bayongbong ini dalam keadaan sehat, namun untuk tingkat kesadaran terhadap kesehatan masih kurang yang ditandai dengan pola hidup yang kurang sehat, jarang berolahraga dan jarangnya memeriksaan diri kepelayanan kesehatan. Selain itu, terjadi peningkatan pengetahuan pada sebagian besar peserta setelah webinar yang ditandai kenaikan nilai antara nilai pre-test dengan nilai post-test. Hasil kegiatan sosialisasi ini diharapkan dapat memotivasi para guru dan pengajar untuk lebih meningkatkan promosi kesehatan maupun pengetahuan mengenai Covid-19
\end{abstract}

Kata kunci: Covid-19; webinar; sosialisasi

ABSTRACT. Coronavirus Disease 2019 (COVID-19) pandemi has been going on for quite a while worldwide. Indonesia government has established the pandemi as emergency disaster. The transmission has been continously prevented through rigid protocol. However, the obedience of people to follow the protocol strictly remains challenging. Praktek Pembangunan Kesehatan Masyarakat (PPKM) is an educational program involving senior students to investigate as well as to solve the ongoing health issues in society. This year, the activity was carried out in an online seminar (webinar) entitled "Putuskan Rantai Penyebaran Covid! Pengentahuan, Pencegahan dan Pemberantasan (3P" which was aimed to students of Health Analyst in SMK Bhakti Kencana, Bayongbong, Garut. This event provides updated information in regards of Covid-19 diagnostic tests which is appropriate and valuable to the students. Furthermore, evaluation of knowledges of participants were also done based on quistionnaire. The results showed that students were healthy, however, sort of ignored the Covid-19 protocol on daily basis. After webinar, there was an escalation in knowledges of participant as shown in higher grades from post-test. Overall, the webinar went well and hopefully encourage both teachers and students to be more dicipline in implementing Covid-19 protocol.

Key words: Covid-19; webinar; sosialisation

\section{PENDAHULUAN}

Pada saat ini dunia sedang dilanda pandemi yang cukup mengkhawatirkan, yaitu Coronavirus Disease 2019 atau yang biasa disebut Covid-19. Covid-19 merupakan penyakit menular yang disebabkan oleh severe acute respiratory syndrome coronavirus 2 atau SARS-CoV-2 (Fitria \& Ifdil, 2020). Pemerintah Indonesia telah menetapkan status darurat bencana yang terkait dengan pandemi virus ini (Kemenkes, 2020). Pemutusan rantai penularan bisa dilaksanakan dengan menerapkan protokol kesehatan secara disiplin yaitu dengan cara sering mencuci tangan dengan air mengalir dan sabun atau menggunakan hand sanitizer, menggunakan masker dan tidak menyentuh area muka sebelum mencuci tangan, serta menjaga jarak dalam setiap berkegiatan atau yang dikenal dengan istilah 3M (Anggreni \& Safitri, 2020). Pemerintah juga telah membuat kebijakan untuk menerapkan physical distancing untuk memutuskan penyebaran Covid-19. Masyarakat dihimbau untuk tidak melakukan kontak langsung dengan orang lain, menghindari pertemuan yang bersifat massal. Aktivitas bekerja, belajar dan beribadah dilaksanakan di rumah (Saadat et al, 2020).

Akan tetapi, masih banyak masyarakat yang tidak mengikuti anjuran tersebut. Siswa dan mahasiswa yang proses belajar mengajar dilakukan dari rumah memanfaatkan waktu itu untuk berlibur, berekreasi ke mall, bioskop, atau kepuncak. Remaja dan orang muda harus meningkatkan kesiapsiagaan terhadap penyakit ini (Natalia et al., 2020).

Prosedur pengujian yang akurat, mudah dan cepat dapat membantu menghilangkan penyebaran 
COVID-19 oleh orang dengan kasus asimtomatik. Hal in dilakukan untuk menghindari karantina yang tidak perlu pada individu negatif dan penyebaran infeksi oleh individu positif. Diagnosis dini memungkinkan dokter untuk memberikan intervensi segera bagi pasien yang berisiko lebih tinggi, agar tidak berkembang komplikasi yang lebih serius dari COVID19 (Carter et al, 2020). Reverse Transcription-Polymerase Chain Reaction (RT-PCR) adalah metode yang dirujuk oleh WHO sebagai gold standard diagnosis infeksi SARSCoV-2 (World Health Organization, 2020). Metode RT-PCR berfungsi mendeteksi adanya virus dalam tubuh pasien melalui reaksi rantai polimerase dengan primer yang secara spesifik menargetkan genom SARS-CoV-2 (Bai et al, 2020). Respons antibodi manusia untuk melawan virus pada awal infeksi dapat juga digunakan untuk mendukung diagnosis infeksi virus. Salah satu metode yang dapat digunakan untuk mengetahui adanya antibodi di dalam tubuh adalah rapid test antibody. Rapid test antibody mampu mendeteksi antibodi dalam waktu 5-30 menit, dan proses pemeriksaannya juga cukup cepat dan sederhana (Koczula \& Gallotta, 2016; Bai et al., 2020). Di Indonesia pemeriksaan rapid test antibody digunakan sebagai pemeriksaan skrining masal COVID-19, sementara pemeriksaan RT-PCR dijadikan pemeriksaan konfirmasi adanya SARSCoV-2 di dalam tubuh (Long et al, 2020).

Salah satu tenaga kesehatan penting di era pandemi COVID-19 adalah analis kesehatan atau sekarang dikenal dengan Ahli Teknologi Laboratrium Medis (ATLM). ATLM memiliki peran kunci dalam penegakan diagnosa COVID-19 yaitu melakukan analisis terhadap cairan tubuh pasien meliputi sampel usap (swab) dari tenggorokan pasien, maupun sampel darah pasien. Pemeriksaan yang dilakukan oleh ATLM menentukan tindakan selanjutnya yang akan diberikan pada pasien. ATLM perlu meningkatkan penguasaan ilmu pengetahuan dan teknologi dalam bidang laboratorium yang dapat dilakukan melalui pendidikan formal maupun non formal.

Sehubungan dengan latar belakang tersebut, maka dilakukannya kegiatan Praktek Pembangunan Kesehatan Masyarakat (PPKM) yang merupakan suatu bentuk pendidikan dengan cara memberikan pengalaman belajar kepada mahasiswa untuk dapat mengidentifikasi serta menangani masalahmasalah pembangunan kesehatan yang dihadapi di masyarakat. Di tengah pandemi ini, PPKM dilakukan secara daring melalui pelaksanaan Webinar "Putuskan Rantai Penyebaran Covid! Pengentahuan, Pencegahan dan Pemberantasan $(3 P)$ " dengan peserta adalah siswa/i jurusan Analis Kesehatan, SMK Bhakti Kencana, Bayongbong, Garut.

\section{METODE}

Sasaran kegiatan PPKM adalah siswa/i kelas X-XII Jurusan Analis Kesehatan SMK Kesehatan Bhakti Kencana, Bayongbong, Garut. Webinar mengambil judul "Putuskan Rantai Penyebaran Covid! Pengentahuan, Pencegahan dan Pemberantasan (3P)" dan dilaksanakan pada tanggal 16 Desember 2020 yang dimulai pukul 09.00 WIB melalui zoom meeting. Sosialisasi dilakukan terpisah untuk masing-masing kelas. Mahasiswa Prodi TLM (D-3) STIKes Jenderal Achmad Yani tingkat III dilibatkan sebagai panitia pelaksana di bawah bimbingan dosen untuk masing-masing kelas yang terdiri dari: Iis Herawati, S.Pd, M.Kes, Fini Ainun Qolbi Wasdili, M.Si, dan Dwi Davidson Rihibiha, M.Si.

Sebelumnya, dosen pembimbing berkoordinasi dengan pihak sekolah terkait rencana pelaksanaan webinar. Selanjutnya, panitia pelaksana bertugas membuat susunan acara webinar, mendata dan mengumpulkan peserta dalam grup Whatsapp untuk memudahkan komunikasi, mempersiapkan materi paparan, membuat kuisioner berdasarkan pedoman yang sudah diberikan dari pihak kampus, dan menyiapkan doorprize untuk peserta.

Selama webinar peserta diminta mengisi kuisioner berupa data kesehatan diri, serta pre- dan post-test mengenai materi Covid-19 melalui Google Form, kemudian data direkap oleh panitia. Data kemudian diolah dan dibahas di bawah bimbingan dosen pembimbing masing-masing kelompok.

\section{HASIL DAN PEMBAHASAN}

Kegiatan PPKM dilakukan dalam bentuk webinar, yang diinfokan melalui poster (Gambar 1). Sasaran yang dipilih adalah SMK Kesehatan Bhakti Kencana yang merupakan salah satu sekolah kesehatan yang terletak di daerah Bayongbong, Kabupaten Garut, Provinsi Jawa Barat. SMK Bhakti Kencana Garut memiliki 600 siswa dengan 3 jurusan yaitu jurusan Teknologi Laboratorium Medik, keperawatan dan farmasi. Terdapat 12 kelas, memiliki 42 guru dari 3 jurusan dan 381 pelajaran dari 3 jurusan. Pada kegiatan PPKM ini, sosialisasi Covid-19 dilakukan hanya pada siswa/i kelas X-XII Jurusan Analis Kesehatan. Peserta kelas X yang menghadiri sosialisasi berjumlah 29 orang, sedangkan kelas XI yang hadir hanya berjumlah 17 orang dan kelas XII berjumlah 15 orang (Gambar 2). Tidak semua siswa/i mengikuti kegiatan sosialisasi karena kendala sinyal di tempat tinggal mereka sehingga mereka mengalami kesulitan untuk masuk ke dalam Zoom meeting. 




Gambar 1. Poster Webinar Sosialisasi Pencegahan Covid-19

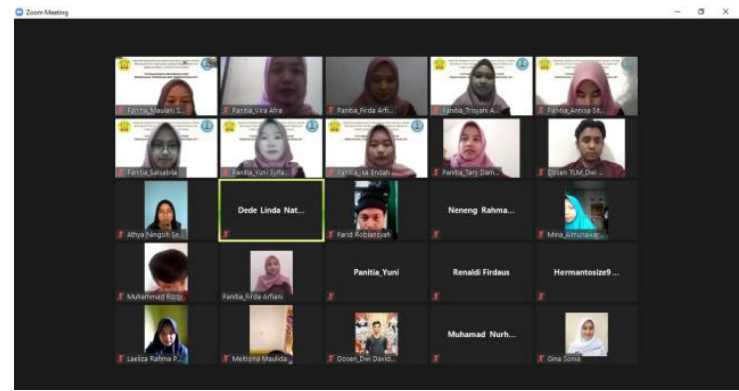

Gambar 2. Peserta Webinar Sosialisasi Pencegahan Covid-19 di SMK Bhakti Kencana Bayongbong

Mahasiswa memberi paparan kepada peserta dalam bentuk slide presentasi dan video dokumentasi tentang pemeriksaan swab untuk dapat membantu meningkatkan pemahaman bagi peserta mengenai materi yang dibahas (Gambar 3). Materi paparan terdiri dari karakteristik virus SARS-CoV-2, penularan Covid-19, upaya pencegahan, dan perkembangan vaksin beserta mekanisme kerjanya. Selain itu, peserta juga dikenalkan dengan jenis-jenis pemeriksaan Covid-19 terutama pemeriksaan yang berbasis molekuler. Sehubungan dengan peserta yang merupakan siswa/i Jurusan Analis Kesehatan, pengenalan terhadap teknik pemeriksaan Covid-19 dirasa sangat penting untuk menambah wawasan dan mempersiapkan mereka sebelum terjun ke dunia kerja.

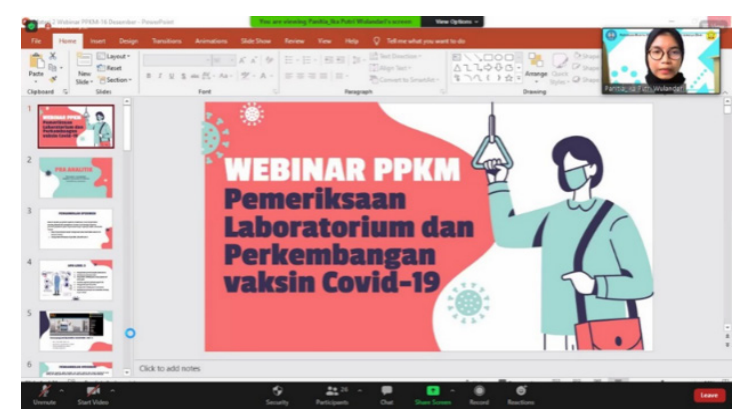

Gambar 3. Pemaparan Materi Sosialisasi Pencegahan Covid-19 di SMK Bhakti Kencana Bayongbong
Evaluasi kegiatan dilakukan dalam bentuk kuisioner. Terdapat dua kuisioner, yaitu kuisioner data kesehatan peserta dan kuisioner tentang pemahaman peserta. Berdasarkan hasil kuisioner data kesehatan (Tabel 1-3), sebagian besar siswa/i Analis Kesehatan SMK Bhakti Kencana dalam keadaan sehat, namun tingkat kesadaran terhadap kesehatan masih kurang yang ditandai dengan pola hidup kurang sehat. Selain itu, tingkat kesadaran terhadap bahaya Covid-19 ini pun juga masih kurang. Hal ini dapat dilihat dari masih seringnya mereka berkumpul di tempat ramai, tidak menjaga jarak, tidak menggunakan pelindung wajah yang efektif, jarang mengganti pakaian setelah berpergian atau mandi setelah melakukan aktivitas di luar, dan tidak melakukan pemeriksaan dini terhadap penyakit Covid-19. Meskipun demikian, para siswa/i sudah melakukan kegiatan yang membantu dalam memberantas penyebaran penyakit Covid-19 antara lain dengan pemakaian masker walaupun masih ada yang menggunakan masker kain yang keefektifannya masih kurang, tidak berpegian keluar daerah, tidak menggunakan kendaraan umum yang kemungkinan terpapar, dan sering melakukan cuci tangan.

Tabel 1. Hasil kuisioner data kesehatan kelas X Jurusan Analis Kesehatan SMK Bhakti Kencana Garut

\begin{tabular}{|c|c|c|c|}
\hline \multirow{2}{*}{ No. } & \multirow{2}{*}{ Variabel } & \multicolumn{2}{|c|}{ Jumlah } \\
\hline & & $\mathbf{n}$ & $\%$ \\
\hline \multirow[t]{7}{*}{1} & Riwayat penyakit & & \\
\hline & Maag & 4 & $13,8 \%$ \\
\hline & Asam Lambung & 3 & $10,3 \%$ \\
\hline & Radang Usus & 1 & $3,4 \%$ \\
\hline & Tipoid & 1 & $3,4 \%$ \\
\hline & Asma & 1 & $3,4 \%$ \\
\hline & Tidak ada & 19 & $65,7 \%$ \\
\hline \multirow[t]{6}{*}{2} & Keadaan saat ini & & \\
\hline & Sakit & 3 & $10.3 \%$ \\
\hline & Tidak sakit & 26 & $89,7 \%$ \\
\hline & Penanganan ketika sakit & & \\
\hline & Berobat ke pelayanan kesehatan & 24 & $82,8 \%$ \\
\hline & Konsumsi obat sendiri & 5 & $17,2 \%$ \\
\hline \multirow[t]{4}{*}{3} & Berolahraga & & \\
\hline & $\mathrm{Ya}$ & 2 & $6,9 \%$ \\
\hline & Tidak & 4 & $13,8 \%$ \\
\hline & Kadang-kadang & 23 & $79,3 \%$ \\
\hline \multirow[t]{3}{*}{4} & $\begin{array}{l}\text { Berpergian ke luar Kota dalam waktu } 14 \\
\text { hari terakhir }\end{array}$ & & \\
\hline & $\mathrm{Ya}$ & 2 & $6,9 \%$ \\
\hline & Tidak & 27 & $93,1 \%$ \\
\hline \multirow[t]{3}{*}{5} & $\begin{array}{l}\text { Mengalami demam diatas dalam waktu } 14 \\
\text { hari terakhir }\end{array}$ & & \\
\hline & $\mathrm{Ya}$ & 0 & $0 \%$ \\
\hline & Tidak & 29 & $100 \%$ \\
\hline \multirow[t]{3}{*}{6} & $\begin{array}{l}\text { Mengalami gejala Covid-19 dalam waktu } \\
14 \text { hari terakhir }\end{array}$ & & \\
\hline & $\mathrm{Ya}$ & 0 & $0 \%$ \\
\hline & Tidak & 29 & $100 \%$ \\
\hline \multirow[t]{3}{*}{7} & Berada di tempat berkerumun & & \\
\hline & Ya & 3 & $10,3 \%$ \\
\hline & Tidak & 26 & $89,7 \%$ \\
\hline
\end{tabular}




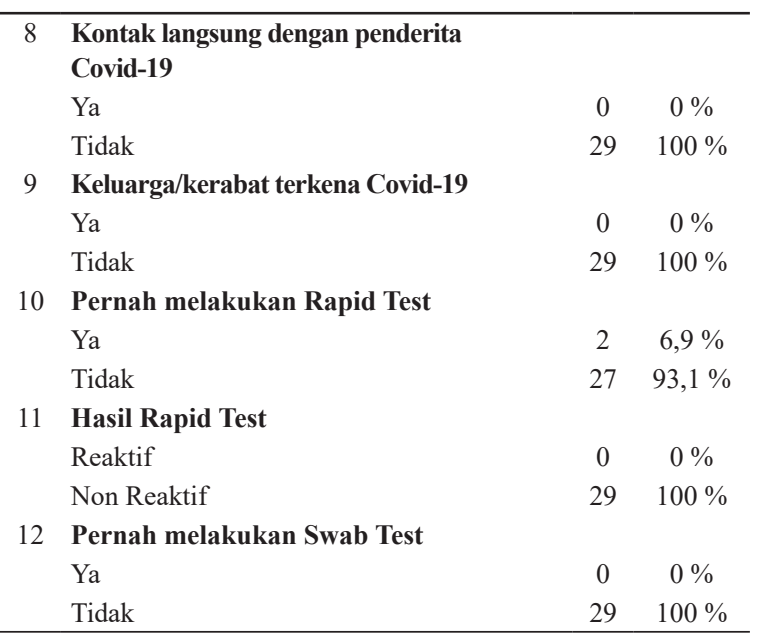

Tabel 2. Hasil kuisioner data kesehatan kelas XI Jurusan Analis Kesehatan SMK Bhakti Kencana Garut

\begin{tabular}{|c|c|c|c|}
\hline \multirow{2}{*}{ No } & \multirow{2}{*}{ Variabel } & \multicolumn{2}{|c|}{ Jumlah } \\
\hline & & $\mathbf{n}$ & $\%$ \\
\hline \multirow[t]{4}{*}{1} & Riwayat penyakit & & \\
\hline & Sehat & 13 & 76,4 \\
\hline & Maag & 2 & 11,7 \\
\hline & Anemia & 2 & 11,7 \\
\hline \multirow[t]{3}{*}{2} & Sedang menderita sakit/tidak & & \\
\hline & Sehat & 14 & 82,3 \\
\hline & Sakit & 3 & 17,6 \\
\hline \multirow[t]{3}{*}{3} & Gejala yang dirasakan & & \\
\hline & Tidak ada & 9 & 52,9 \\
\hline & Terdapat gejala & 8 & 47,1 \\
\hline \multirow[t]{3}{*}{4} & Cara mengatasi penyakit & & \\
\hline & Berobat ke sarana pelayanan kesehatan & 8 & 47,1 \\
\hline & Diobati sendiri & 9 & 52,9 \\
\hline \multirow[t]{4}{*}{5} & Kegiatan olahraga & & \\
\hline & $\mathrm{Ya}$ & 4 & 23,5 \\
\hline & Tidak & 12 & 70,6 \\
\hline & Kadang-kadang & 1 & 5,8 \\
\hline \multirow[t]{3}{*}{6} & $\begin{array}{l}\text { Pernah mengalami demam dengan suhu } \\
\text { tubuh diatas } 37^{\circ} \mathrm{C}\end{array}$ & & \\
\hline & Ya & 0 & 0 \\
\hline & Tidak & 17 & 100 \\
\hline \multirow[t]{3}{*}{7} & $\begin{array}{l}\text { Riwayat perjalanan keluar kot dalam } \\
\text { waktu } 14 \text { hari terakhir }\end{array}$ & & \\
\hline & Ya & 0 & 0 \\
\hline & Tidak & 17 & 100 \\
\hline \multirow[t]{3}{*}{8} & Anda sering berada ditempat yang banyak orang & & \\
\hline & Ya & 3 & 17,6 \\
\hline & Tidak & 14 & 82,4 \\
\hline \multirow[t]{3}{*}{9} & $\begin{array}{l}\text { Pernah kontak erat dengan orang kasus } \\
\text { terkonfirmasi Covid-19 }\end{array}$ & & \\
\hline & Ya & 1 & 5,8 \\
\hline & Tidak & 16 & 94,2 \\
\hline \multirow[t]{3}{*}{10} & Ada keluarga/kerabat yang terkena Covid-19 & & \\
\hline & $\mathrm{Ya}$ & 0 & 0 \\
\hline & Tidak & 17 & 100 \\
\hline \multirow[t]{3}{*}{11} & Pernah melakukan pemeriksaan rapid test & & \\
\hline & $\mathrm{Ya}$ & 2 & 11,7 \\
\hline & Tidak & 15 & 88,3 \\
\hline \multirow[t]{3}{*}{12} & $\begin{array}{l}\text { Pernah melakukan pemeriksaan swab } \\
\text { (RT-PCR) }\end{array}$ & & \\
\hline & Ya & 2 & 11,7 \\
\hline & Tidak & 15 & 88,3 \\
\hline
\end{tabular}

Tabel 3. Hasil kuisioner data kesehatan kelas XII Jurusan Analis Kesehatan SMK Bhakti Kencana Garut

\begin{tabular}{|c|c|c|c|}
\hline \multirow{2}{*}{ No } & \multirow{2}{*}{ Variabel } & \multicolumn{2}{|c|}{ Jumlah } \\
\hline & & $\mathbf{n}$ & $\%$ \\
\hline \multirow[t]{4}{*}{$\overline{1}$} & Riwayat penyakit & & \\
\hline & Sehat & 8 & 67 \\
\hline & Maag & 3 & 25 \\
\hline & Anemia & 1 & 8 \\
\hline \multirow[t]{3}{*}{2} & Sedang menderita sakit/tidak & & \\
\hline & Sehat & 12 & 100 \\
\hline & Sakit & 0 & 0 \\
\hline \multirow[t]{3}{*}{3} & Gejala yang dirasakan & & \\
\hline & Tidak ada & 12 & 100 \\
\hline & Terdapat gejala & 0 & 0 \\
\hline 4 & Cara mengatasi penyakit & & \\
\hline
\end{tabular}

4 Cara mengatasi penyakit

$\begin{array}{lll}\text { Berobat ke sarana pelayanan kesehatan } & 8 & 67\end{array}$

Diobati sendiri $\quad 4 \quad 33$

5 Alasan jika tidak berobat

Kendala biaya

Malas dalam berobat

Takut berobat

6 Kegiatan olahraga

Ya

Tidak

Kadang-kadang

$7 \quad$ Pola hidup yang tidak sehat

$\begin{array}{lll}\text { Pola tidur yang tidak sehat (begadang) } & 9 & 75\end{array}$

Mengkonsumsi makanan junk food $\quad 3 \quad 25$

8 Memakai masker ketika diluar

$\mathrm{Ya}$

Kadang-kadang

1198

9 Masker yang digunakan

Masker kain

Masker medis

10 Informasi yang didapat tentang Covid berasal dari

Media social

TV

Penyuluhan

11 Pernah mengalami demam dengan suhu tubuh diatas $37^{\circ} \mathrm{C}$

Ya

Tidak

$12 \quad 100$

12 Gejala pada hari ini atau dalam waktu 14 hari terakhir

Nyeri tenggorokan

Batuk, pilek, nyeri tenggorokan

$\begin{array}{lll}\text { Tidak ada } & 10 & 83\end{array}$

13 Riwayat perjalanan keluar kot dalam

waktu 14 hari terakhir

Ya

Tidak

14 Transportasi yang digunakan sehari-hari dalam 14 hari terakhir

Angkutan umum/gojek/gocar $\quad 3 \quad 25$

$\begin{array}{lll}\text { Motor/mobil pribadi } & 9 & 75\end{array}$

15 Tempat keramaian yang dikunjungi dalam waktu 14 hari terakhir

Tempat ibadah $\quad 4 \quad 33$

Sekolah $\quad 2 \quad 17$

Pasar $\quad 4 \quad 33$

$\begin{array}{lll}\text { Mall } & 2 & 17\end{array}$

16 Anda sering berada ditempat yang banyak orang

$\begin{array}{lll}\text { Ya } & 7 & 58\end{array}$

$\begin{array}{lll}\text { Tidak } & 5 & 42\end{array}$ 


\begin{tabular}{rlcc}
\hline 17 & $\begin{array}{l}\text { Pernah kontak erat dengan orang kasus } \\
\text { terkonfirmasi Covid-19 }\end{array}$ & & \\
& Ya & 1 & 8 \\
& Tidak & 11 & 92 \\
18 & $\begin{array}{l}\text { Ada keluarga/kerabat yang terkena } \\
\text { Covid-19 }\end{array}$ & & \\
& Ya & 0 & 0 \\
& Tidak & 12 & 100 \\
19 & $\begin{array}{l}\text { Disekitar tempat tinggal anda ada yang } \\
\text { terkena Covid-19 }\end{array}$ & & \\
& Ya & 1 & 8 \\
& Tidak & 11 & 92 \\
20 & $\begin{array}{l}\text { Pernah isolasi mandiri } \\
\text { Ya }\end{array}$ & & \\
& Tidak & 1 & 8 \\
21 & $\begin{array}{l}\text { Pernah melakukan pemeriksaan rapid test } \\
\text { Ya }\end{array}$ & 11 & 92 \\
& Tidak & 0 & 0 \\
22 & $\begin{array}{l}\text { Pernah melakukan pemeriksaan swab } \\
\text { (RT-PCR) }\end{array}$ & 12 & 100 \\
& Ya & & \\
Tidak & & 0 & 0 \\
\hline & & 12 & 100 \\
\hline
\end{tabular}

Kuisioner pemahaman peserta dibagi menjadi dua, yaitu kuisioner pengetahuan awal (pre-test) yang diberikan sebelum peserta mendapatkan materi, dan yang kedua adalah kuisioner pengetahuan akhir (post-test) yang diberikan setelah paparan materi. Berdasarkan hasil post-test, terlihat adanya perbedaan dengan hasil pre-test dimana terjadi kenaikan (Gambar 4). Seluruh siswa/i kelas $X$ menunjukkan peningkatan pengetahuan setelah webinar. Sebanyak $60 \%(9 / 15)$ siswa/i kelas XI dan 83\% (10/12) siswa/i kelas XII juga menunjukkan peningkatan. Kenaikan ini menunjukan bahwa pengetahuan dari siswa/i meningkat. Jumlah siswa/i yang mengalami peningkatan lebih tinggi dibandingkan dengan yang mengalami penurunan atau yang tidak mengalami perubahan sama sekali.
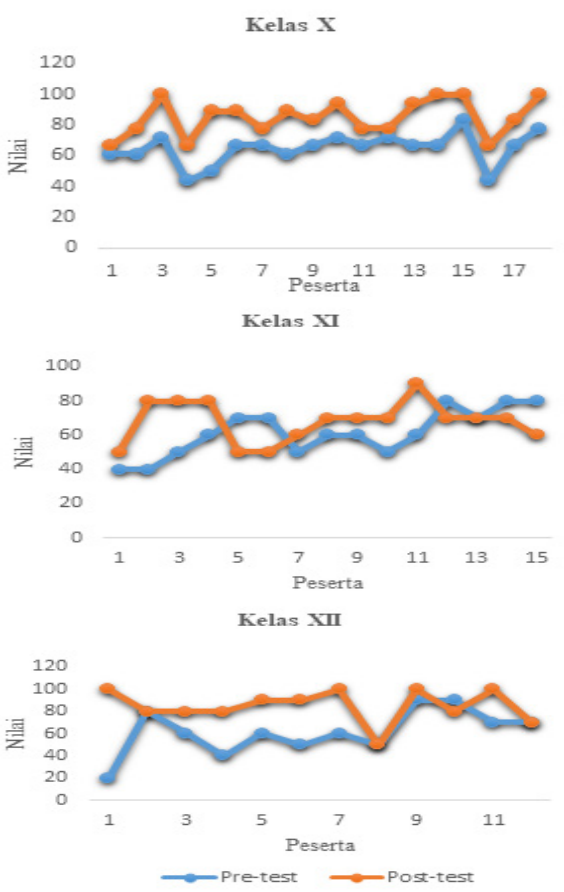

Gambar 4. Peningkatan pengetahuan peserta webinar
Hasil kegiatan sosialisasi ini diharapkan dapat memotivasi para guru dan pengajar untuk lebih meningkatkan promosi kesehatan maupun pengetahuan mengenai Covid-19 agar siswa/i senantiasa mengenal dan memahami dampak dan cara penanganan yang harus diterapkan. Selain itu, untuk kegiatan PPKM selanjutnya dapat disertai juga dengan pemeriksaan laboratorium sehingga masalahmasalah kesehatan dalam masyarakat dapat terdeteksi.

\section{SIMPULAN}

Kegiatan webinar berlangsung dengan lancar, dan peserta yaitu siswa/i jurusan Analis Kesehatan SMK Bhakti Kencana, Bayongbong, Garut juga menunjukkan peningkatan dalam pengetahuan terkait perkembangan dan teknik pemeriksaan Covid-19.

\section{DAFTAR PUSTAKA}

Anggreni, D., Safitri, C.A. (2020). Hubungan Pengetahuan Remaja Tentang Covid-19 Dengan kepatuhan Dalam menerapkan protokol Kesehatan Di Masa New Normal. HOSPITAL MAJAPAHIT Vol 12 No. 2 November 2020. 12(2), 134-142.

Bai, H., Cai, X., \& Zhang, X. (2020). A comparison of PCR vs Immunoassay vs Crispr-Based test. OSF Preprints.

Carter LJ, Garner L V., Smoot JW, Li Y, Zhou Q, Saveson CJ, et al. Assay Techniques and Test Development for COVID-19 Diagnosis. ACS Central Science. 2020;6(5):591

Fitria, L., \& Ifdil, I. (2020). Kecemasan remaja pada masa pandemi Covid -19. Jurnal EDUCATIO: Jurnal Pendidikan Indonesia, 6(1), 1.

Kementrian Kesehatan RI. Pedoman Pencegahan dan Pengendalian Coronavirus Disease (COVID-19). Kementerian Kesehatan. 2020. Available from: https://covid19. go.id/storage/ app/media/Protokol/ 2020/Juli/REV-05 Pedoman_P2_COVID-19_13_Juli_2020.pdf

Koczula, K. M., \& Gallotta, A. (2016). Lateral flow assays. Essays in Biochemistry, 60(1),111120.

Long, C., Xu, H., Shen, Q., Zhang, X., Fan, B., Wang, C., ... Li, H. (2020). Diagnosis of the Coronavirus disease (COVID-19): rRT-PCR or CT? European Journal of Radiology, 126, 108961

Natalia, R. N., Malinti, E., \& Elon, Y. (2020). Kesiapsiagaan Remaja Dalam Menghadapi Wabah Covid-19. Jurnal Ilmiah Kesehatan Diagnosis, 15(2), 2302-2531. 
Saadat S, Rawtani D, Hussain CM. Environmental perspective of COVID-19. Science of the Total Environment. 2020;728:1-2
World Health Organization. (2020). Laboratory testing for coronavirus disease (COVID-19) in suspected human cases. WHO - Interim Guidance, (19 March), 1-7. 